\title{
PRAGMATIC ASPECTS OF PERSUASION AND MANIPULATION IN WRITTEN ADVERTISEMENTS*
}

\author{
ANETT ÁRVAY
}

\begin{abstract}
One way of exerting influence is realized by the use of language. According to the communicative intention of the influencer, thoroughly designed strategic discourse can be either persuasive or manipulative. First, the present research separates persuasion from manipulation in an interdisciplinary - pragmatic and social psychologicalframework. Four possible types of manipulation are identified in the paper: (i) withholding certain propositions, (ii) informing without ostensive communicative intention to the intended addressee, (iii) using linguistically and logically correct elements that force an unconditional and unquestioning agreement and (iv) using fallacious argumentation. The second part of the paper investigates how persuasion and manipulation work in written advertisements in Hungarian, what kind of strategies and linguistic tools are used to influence readers. A Hungarian and an American direct mail message are analyzed to see whether the Hungarian strategies identified exist in English or they are language-specific. It is argued that they work in English as well.
\end{abstract}

\section{Introduction}

One way of exerting influence on other people is realized by the use of language. The aim is to change attitudes, opinions of readers and listeners or strengthen their already existing opinions and attitudes. According to the communicative intention of the influencer, the thoroughly designed strategic discourse can be either persuasive or manipulative. The present research attempts 1 . to separate persuasion from manipulation on the theoretical level in an interdisciplinary framework; 2. to take a closer look at what kind of strategies and linguistic tools are used in Hungarian written advertisements to influence readers; and 3. to see whether the Hungarian strategies identified exist in English or whether they are language-specific.

According to the above-mentioned aims, the paper is organized as follows. Section 2. defines the key terms; separates persuasion from manipulation in the light of significant pragmatic theories; reviews the results of relevant social psychological experiments; and finally outlines

* I would like to thank Enikő Németh T., Károly Bibok and the two anonymous reviewers for their insightful comments on an earlier draft of this article.

1216-8076/\$20.00 (c) 2004 Akadémiai Kiadó, Budapest 
four types of manipulative strategies. In section 3. manipulative and persuasive strategies are analysed in Hungarian and English written advertisements. Section 4. makes some concluding remarks.

\section{Separating persuasion from manipulation}

\subsection{Definitions of persuasion and manipulation}

Persuasion is a widely known and used phenomenon in human communication. Even in ancient times a separate field of study, rhetoric was devoted to its theory and practice. The major aim of ancient rhetorical schools (e.g., Protagoras, Gorgias, Aristotle, Cicero, Isocrates, Quintilian) was to train students to present a speech in public in order to convince their audience on various public issues, and trials. Besides discussing and memorizing persuasive tools, the sophists did not deter from applying and teaching false argumentation (logical fallacies), since the success of the speaker in winning the audience was the chief goal (Szálkáné Gyapai 1999).

Like persuasion, manipulation belongs to the category of social influencing. Both are goal-oriented, the aim of the communicator is to form or change (or sometimes maintain) a certain opinion or attitude in a given subject, according to the communicator's interest. In the case of advertisement, the prime aim is to help the audience form a positive attitude toward a product or service in order to become potential customers.

According to Webster's dictionary (1998), to persuade is to "move by argument, entreaty, or expostulation to a belief, position or course of action." Argument targets the rational part of the receiver, whereas the other two do not. Similarly to the dictionary definitions, Aristotle claimed that besides logical arguments (logos), persuasion is often based on a reputation for credibility (ethos) and emotional appeals (pathos) (Szálkáné Gyapai 1999). Contemporary psychological and social psychological research justified the importance of the role of emotions in persuasion (Brembeck-Howell 1952; Janis-Hovland 1959; Littlejohn 1983; Walton 1989; 1992).

To manipulate means (Webster's dictionary 1998) "to control or play upon by artful, unfair or insidious means especially to one's own advantage." Manipulation is artful, hence the victims do not even recognize/ realize that they are being manipulated because the manipulative dis- 
course does not use a direct conviction but rather camouflages its real intention.

Parret (1994, 230-1) regards manipulation as a unilateral, semifailed, truncated action, where the manipulator's intention is supported by his/her cognitive and pragmatic competence, and leading to his/her intervention, implying a performance on the part of the manipulated party. The manipulated party's potential response positions are limited to impotence, obeyance or indifference. The cardinal feature of manipulation is that it puts the initial contract between the participants at risk and elicits the return to an uncontrollable polemic.

Harré $(1985,127)$ has a similarly moral standpoint. He states that the moral quality of persuasion lies in the fact that the communicator respects his/her audience by treating them as people. Whereas in the case of manipulation the listeners do not participate as conscious and active beings in the flow of communication, the speaker treats them as things.

Breton $(2000,25)$ notes that manipulation is an aggressive and forcible action: it deprives the manipulees from their freedom. He goes on to argue that the majority of the advertisements today contains manipulative utterances and the reason why informative, argumentative ads are in the minority is that they cannot change the attitudes of the potential customers.

All the above definitions and conceptualizations regard manipulation as a negative, non-cooperative and unequal phenomenon; however, it must be noted that there are a few situations where manipulation serves right purposes. Psychotherapy, for instance, uses manipulation in the exact interest of the patient. Although, on the theoretical level, the separation of persuasion and manipulation seems quite clear, according to some scholars (Síklaki 1994; Bańczerowski 1997b; Breton 2000) to separate them in practice is a very difficult task. No wonder that hardly any concrete analyses can be read on the topic.

In the following two sections the relevant pragmatic theories will be discussed along with some social psychological experiments to illustrate the process and the effect of persuasion and manipulation.

\subsection{Pragmatic approaches}

Manipulative communication will be discussed first within the framework of Sperber and Wilson's (1995) influential and well-known theory that is 
offered as a cognitive model of human communication. The model of ostensive-inferential communication is comprehensive and dynamic because both parties participating in the flow of communication are considered of equal importance, and therefore it provides a possibility to trace where and how manipulation can occur.

Sperber and Wilson combined the former code-models and inferential models, and thus solved the problem of inaccurate description of verbal communication by complementing the decoding process, which is indispensable to the interpretation of an utterance, with an inferential process (Németh T. 1996, 12).

The definition of ostensive-inferential communication states that "the communicator produces a stimulus which makes it mutually manifest to the communicator and audience that the communicator intends, by means of this stimulus, to make manifest or more manifest to the audience a set of assumptions $\{I\} "$ (Sperber-Wilson 1995, 63). According to the definition, when communication is successful, the informative and the communicative intentions are always present. The former refers to the act of making manifest or more manifest a set of assumptions $\{I\}$ to the audience, the latter means that the communicator has an informative intention and makes it mutually manifest to audience and communicator (Sperber-Wilson 1995, 58-61).

Let us now examine how and to what extent the model describes the mechanism of manipulation. Two verbal manipulative situations will be discussed in the light of the ostensive-inferential communication model. Imagine that a family is playing the strategic and military game Risk, where the purpose is to either occupy territories or to exterminate all the soldiers of one player. Mark wants to make use of Jamie to exterminate Helen's troops that are stationed at Kamchatka. Therefore he utters the following to Jamie:

(1) I think the best move for you would be to attack Kamchatka, so you could reach America quickly.

Jamie understood Mark's informative intention (he was informed with $\{I\}$ : you get to America through Kamtchatka fast, so it is worth attacking), and his communicative intention: that this utterance was said to him. However, he did not understand Mark's motivations that he did not recommend the utterance to make him more successful, but rather to cause him to exterminate Helen's troops. According to Sperber and Wilson's model, this situation should be described as successful, how- 
ever obvious it is that the communicative partner did not understand everything, or possess all the relevant information. This situation can be regarded as manipulation, since some information remained hidden and the real intention of the communicator (to use Jamie to attack Helen's troops) was camouflaged. Jamie, the addressee, was able to decode the linguistic stimulus, but he was unable to recognize the real intention of the speaker, therefore he came to the wrong implication. He regarded the utterance as honest; moreover, Jamie did not even understand that the attack would be primarily advantageous for Mark. The question now lies in the following: where is the hidden information (the attack of Helen's troops is best for Mark) and the manipulative intention (do the dirty job instead of me without knowing what you are doing) situated? In SperberWilson's model this hidden information can only be in $\{I\}$. However, the answer is not satisfying. In the example quoted, two different actions took place on two different layers. On the first, surface layer there was a successful communication, the communicator uttered $\{I\}$ (you can quickly reach America through Kamchatka, therefore it is worth attacking), and this informative intention became obvious. On the second, hidden layer, neither informative nor communicative intention was attached to $\left\{I_{2}\right\}$ (the attack will be best for Mark; do the job instead of me). Mark did not make it mutually manifest that he intended to convey a particular piece of information, therefore Mark manipulated his partner.

Now, let us consider another situation. At a party Susan learns that Tom is hesitating whether to travel to Bangkok or to Rio de Janeiro. Susan worries for Tom but she does not dare to admit it to him face to face. Therefore she wants to influence Tom by addressing a question to Kate while knowing that Tom is nearby and could hear what she is asking. Susan asks Kate:

(2) Have you heard about the terrible epidemic in Bangkok?

In this situation the informative intention was fulfilled: Susan wanted to inform Tom about the epidemic, whereas she did not have a communicative intention towards Tom, i.e., she did not want Tom to know that the utterance was addressed to him as well. However, there is another layer of the content of informative intention because Susan also had a persuasive intention towards Tom, at the same time she did not want to communicate it to him. Therefore, according to Sperber and Wilson's model situation (2) cannot be regarded as communication in a twofold sense: Susan intended to inform Tom about the epidemic in Bangkok and about 
her persuasive intention but she had a communication intention neither with respect to the information about the epidemic, nor in connection with the information about her persuasive intention. By informing Tom but not communicating with him, Susan manipulated Tom. ${ }^{1}$

The two situations that were analyzed above can both fall into the category of manipulation irrespective of the language in which information conveyed in (1) and (2) was expressed, since manipulation was realized in the malfunctioning of the communicative situations and not by semantic elements or syntactic structures.

Harder and Kock's (1976) theory of presupposition failure accords with the ostensive-inferential communication model described above. Harder and Kock explain manipulation with the lack of mutual knowledge (of either facts or feelings or intentions), which in their article means that the communicator does not place all the information at the communicative partner's disposal, something is hidden from the partner that would be indispensable for him/her to understand the utterance. In the case of honest communication, the communicator knows that his/her partner knows that he/she is being influenced, so they share mutual knowledge. When manipulation occurs, communication is asymmetric; the communicator wants the partner not to know that he/she is being manipulated. If the communicator does not believe what he/she states (e.g., Susan knows that there is no epidemic in Bangkok), the situation is labelled by Harder and Kock as treacherous manipulation.

Besides the ostensive-inferential model of Sperber and Wilson, manipulation is examined within another prevalent pragmatic theory, the Gricean Cooperative Principle and the conversational maxims of Quantity, Quality, Relation and Manner (Grice 1975). Since the definitions of manipulation all agree that it is a deceptive, unequal and non-cooperative way of communicating, it seems reasonable to apply a normative frame like the Gricean model. Relevance theorists criticize the Gricean model for its one-sided, hearer-oriented nature, in fact Taillard $(2000,153)$ in her article asserts that the theory of communication that is based on the necessity of cooperation is bound to fail. Nonetheless, she admits that in some non-cooperative forms of communication such as marketing communication it does offer help for analysis. In this paper the maxims will be considered as reference points. Grice himself emphasizes the impor-

\footnotetext{
${ }^{1}$ It can also happen that Susan wants to influence and manipulate Tom by addressing a question to Kate without an intention to inform Tom about her persuasive intention.
}

Acta Linguistica Hungarica 51, 2004 
tance of the first maxim of the category Quality, which states: Do not say what you believe to be false. He also claims that the rest of the maxims function only if this first one is observed.

During the complex analysis of manipulative and persuasive discourse, the speaker-centered speech act theory (Austin 1962; Searle 1969; 1976) is applied to characterize the writer's persuasive or manipulative strategies. In the present study the speech acts of the ads are analysed according to Searle's (1976) categorization of illocutionary acts: 1. assertives (the speaker reports the existence of a fact); 2 . directives (the speaker's intention is to make the hearer do something); 3. comissives (the speaker commits himself/herself to doing something); 4. expressives (referring to the psychic state of the propositional content); or 5. declaratives (warranting propositional content). This classification is important in actual analysis, but offers no help in separating persuasion from manipulation. As far as the universality of performatives is concerned, crosscultural differences may exist, hence several performatives are related to culture-specific rituals (Thomas 1995, 43).

\subsection{Social psychological approach}

The study of social influence is the central topic of social psychology (Allport 1968; Aronson 1972). The first experiments in the 1940s aimed at determining the key factors of persuasive communication (Hovland et al. 1953), but unfortunately very few were identified. New influenceeoriented theories and research that focussed on the success of persuasion proved to be more fruitful. One of these theories is Petty and Cacioppo's (1981) cognitive-response paradigm, according to which every persuasion carried out by communication is self-persuasion, which is formed by the background knowledge of the hearer. When the stored knowledge and opinion is similar to that of the discourse, the hearer is easily willing to accept the communicated message. This idea was further refined by Petty and Cacioppo in their elaboration likelihood model (1986). They differentiated between the central and peripheral route of changing opinions and attitudes. The persuasiveness of the same discourse is judged differently by various receivers according to their interests, involvement, motivation and momentary state. Attitude change follows the central route when the hearer is involved and motivated, evaluates the discourse, and considers the seriousness, quality, importance and relevance of the arguments, whereas the peripheral route is at work when the receiver does 
not make too much effort in comprehension and his/her evaluation of the discourse is based on incidental aspects, such as surface and non-content features (e.g., the number of arguments, the speaker's characteristics, and the reliability of the source). It must be noted that in many situations both routes are present at the same time but not to an equal extent.

If we accept that the "victim" of manipulation is not aware of being manipulated, and hence cannot do anything against it, then the explanation of how manipulation occurs should be looked for in research that examines the effect of stimulus under the threshold level. Key (1972) was the first who revealed that ads can work on two levels: beneath the surface of the conscious persuasive message, there can be another message exerting influence.

During discourse comprehension certain linguistic tools can function subconsciously. These are called metasemantic features by Semin and De Poot (1997). In their empirical study they investigated how the choice of verb in question formulation influenced respondents' answers. The result showed the manipulative effect of question formulation: the type of the verb (static vs. dynamic) influenced significantly the answers of the respondents.

In her experiment, Loftus (1979) proved the manipulative effect of the definite article. A question was posed to participants in two forms: whether they could see broken headlights, or whether they could see the broken headlights. Those whom the definite article version was asked answered twice more often that they had seen broken headlights, even if there were no broken headlights at all.

The effect of thematic roles has also been proven in a study by Trew (1979). In his study he compared two articles reporting on the same event (the clash between Caribic youngsters and the police) but reporting differently. In one of these articles the Caribic youngsters were significantly more often in the agent role, whereas the policemen in patient role, which suggests that different ideological standpoints resulted in different thematic roles. This can obviously manipulate the readership who do not even have a reason for suspicion, since they read a linguistically correct text.

Howard-Kerin (1994) investigated the persuasive effect of the order of rhetorical questions and arguments. In their empirical study they found that if rhetorical questions are placed after arguments, the persuasive power of the discourse increases. 
The studies mentioned above were all carried out in English, and they all proved that a linguistic stimulus can have subconscious effect, and thus can accomplish manipulation.

The previous two sections (2.2., 2.3.) discussed manipulation from the point of view of pragmatics and social psychology. These two fields were integrated by Taillard (2000) into a unified model of persuasive communication that was based on relevance theory (Sperber-Wilson 1995) (thus non-normative in nature) and claimed to be able to systematically explain how persuasive stimuli are understood and how persuasive intention is fulfilled. Besides relevance theory, the model incorporates the elaboration likelihood model (Petty-Cacioppo 1986), the heuristic systematic model (Chaiken et al. 1989), attribution theory (Kelley 1967; EaglyChaiken 1993) and the persuasion knowledge model (Friestad-Wright 1994). One of the core elements of the model is persuasion knowledge, which enables the target (i.e., receiver) to identify the persuasion attempt and the agent's (i.e., the communicator's) goal (Taillard 2000, 162). Despite the fact that the model does not mention manipulation proper, some of the comprehension routes outlined describe manipulation.

\subsection{Four types of manipulative strategies}

From the communicator's point of view manipulation can be defined as follows: a manipulative intention is present and always leads to a manipulative strategy. The aim of the communicator is to make the receiver(s) accept a fact or opinion, i.e., according to 2.2., $\{I\}$. $\{I\}$ can be true or false; however, the strategy applied in order to force acceptance does not fulfil the criteria of cooperative communication.

Manipulation can be regarded as successful if the receiver believes, accepts, and considers the utterance as true and valid and in the meantime does not recognize that he/she was manipulated. Based on the aforementioned criteria, manipulation can be realized by the following strategies: (i) withholding certain proposition(s); (ii) informing without ostensive communicative intention to the intended addressee; (iii) using linguistically and logically correct elements that force an unconditional and unquestioning agreement; and (iv) using fallacious argumentation.

The strategies listed are not mutually exclusive; in a given discourse all four can be applied and can strengthen the manipulative effect. Let us see in detail how these manipulative strategies work: 
(i) Proposition(s) withheld. The communicator withholds some of the information and the manipulative intention (see (1)), withholding itself realizes manipulation.

(ii) Lack of communicative intention. The communicator utters $\{I\}$ to his/her partner; however, at the same time there is another addressee of the information who does not know that $\{I\}$ was intended for him/her to recognize the informative intention (see (2)).

(iii) Linguistically correct elements forcing agreement. Certain linguistic elements inherently carry the possibility of manipulation. The processing of these elements goes on during decoding, which is an automatic process, therefore these elements have a subconscious effect, independent of the context. This is the reason why even native speakers fail to notice them. These elements are manipulative because they force agreement on the receivers without the receivers knowing about it. In section 2.3., which discussed the social psychological approach, empirical studies were cited that proved that the thematic roles, the type of the verbs in question formulation, the order of rhetorical questions and arguments, and nouns with the definite article also influence the readers subconsciously and therefore have a manipulative effect. The latter tool belongs to the phenomenon of semantic presuppositions, which can be manipulative if they involve false presuppositions (Kiefer 1983, 52), and thus force the acceptance of a false statement. Semantic presuppositions can be accomplished not only by nouns with the definite article (as mentioned above), but also by, e.g., factive verbs (e.g., know, regret, forgive) whose dependent clause is judged as true, because inner negations and yes/no questions leave presuppositions untouched. This is illustrated by the following Hungarian (3a) and English (3b) advertisements.

(3) (a) Ö [az anyukád] tudja, hogy az Ariel a legmakacsabb ételfoltokat is kiszedi a ruhácskádból.

'She (your mother) knows that Ariel takes out even the most persistent food stains from your clothes.'

(b) Did you know that cardiovascular disease is the \#1 killer in America?

Adjectives in the comparative in contrastive structures also induce presuppositions (with the intensifying word még 'even'). So, ad (4) presupposes that your hair was originally shining and healthy.

(4) Haja még ragyogóbb és egészségesebb, mint valaha.

'Your hair is even more shiny and more healthy than ever.'

Acta Linguistica Hungarica 51, 2004 
With regard to the question of the universality of presuppositions, Kiefer (1983, 78-82) notes that non-universal, idiosyncratic presuppositions certainly exist, since languages differ in their lexica and syntactic structures, but the phenomenon (that if a given presuppositional unit or structure is present in a language then it necessarily causes a specific presupposition) itself is universal.

When such tools are used by the communicator unconsciously (i.e., the manipulative intention is missing), they cannot be regarded as manipulative strategies, only manipulative tools. The more empirical research proves the potential manipulativeness of certain linguistic elements, the more precisely it will be possible to construct and uncover manipulative discourse.

(iv) Fallacious argumentation. It can function as a manipulative strategy provided the communicator uses it in a persuasive discourse. Argumentation is fallacious if the discourse contains one or more false propositions or if the way of argumentation is incorrect. The former type coincides with the Augustinian concept of lie (cf. Kecskés 1998, 406). In this paper a lie that is communicated with a persuasive intention will be regarded as manipulation. Certainly, sometimes it is hard to prove if a proposition is true or false. When the way of argumentation is incorrect, reasoning contains a logical (either formal or informal) mistake whose types were catalogued and named first by Aristotle and then were further enlarged and refined by scholars during the centuries. Using argumentation fallacies is effective among receivers who follow the peripheral route of attitude change; for those who follow the central route, the cognitive effort is greater during discourse processing, which enables them to recognize the fallacies and uncover manipulative intention. If that happens, the linguistic element loses its manipulative effect and the strategy is unsuccessful. Argumentation fallacies characterize the logical structure of a discourse, therefore they must exist in the Hungarian and English languages, where Western ways of logic are accepted and constitute the basic norm.

The various elements of style can also be effective among receivers following the peripheral route. According to Bańczerowski (1997a, 192), evaluations that are coded in words, obscurity (homonyms, polysemes) and very often tropes are not simply persuasive, but rather manipulative tools. Sometimes these tools do not observe the first two maxims of Manner (avoid obscurity of expression; avoid ambiguity), however, it is not obvious when. In the case of style, the Gricean maxims do not help to 
judge whether a stylistic element is persuasive or manipulative. Consequently, stylistic devices cannot be considered as a separate manipulative strategy, rather tools that can become manipulative when applied in fallacious argumentation.

\subsection{Focus on the receiver: detecting manipulative communication}

The previous section discussed the accomplishment of the communicator's strategies. Let us now summarize from the receiver's point of view, how the four manipulative strategies outlined are understood within Taillard's integrated model of persuasive communication $(2000,166)$ and how the strategies observe the Gricean maxims.

(i) On the surface layer an ostensive communication takes place, the informative intention is recognized along with the persuasive intention of the communicator. The communicative partner's persuasive knowledge allocates cognitive resources and the processing goes either in a systematic (comprehensive, analytic, cf. central) or a heuristic (cf. peripheral) way. On the hidden layer, since the communicator withholds certain information, neither informative nor communicative intention is attached to $\left\{I_{2}\right\}$. In a Gricean sense this strategy violates the first maxim of Quantity (make your contribution as informative as it is required (for the current purpose of the exchange)).

(ii) The communication is covert, no communicative intention is attached to $\{I\}$. However, it depends on the communicative situation whether the second addressee (the overhearer) has the chance to recognize the persuasive intention. If there is neither informative nor communicative intention attached to the persuasive intention, then inferential processing takes place and no relevance can be guaranteed. If he/she recognizes the persuasive intention (as he/she was informed with it), persuasive knowledge allocates cognitive resources and the processing goes either in the systematic or the heuristic way. Even if processing is systematic, optimal relevance cannot be assumed, and therefore the result is either some or no persuasion or unintended effects. If heuristic processing occurs, the result is either some or no persuasion. This type of manipulative strategy does not violate any Gricean maxims, since the communicator and the overhearer are not communicating, therefore no cooperation can be expected. 
(iii) This type of manipulative strategy involves two different recovery processes but neither of them can be precisely described by Taillard's model. When linguistically correct elements that can force agreement occur in non-persuasive context (e.g., deceptively asking Have you seen the broken headlights? from an eyewitness when there were no headlights at all), the communication seems ostensive, standard ostensive-inferential processing takes place: the eyewitness recognizes the informative intention but does not recognize the manipulative intention and will interpret the sentence as if there had been headlights. When linguistically correct elements that can force agreement occur in a persuasive context (e.g., (3a) where a factive verb was used with false presupposition in advertising discourse), the communication seems ostensive, and the process is the same as on the surface layer in (i): the informative intention and the persuasive intention are recognized, the communicative partner's persuasive knowledge allocates cognitive resources and the processing goes on either systematically or heuristically. However, the possibility of the manipulative intention being fulfilled is to a much greater extent due to the effect of the presupposition. In a Gricean sense this type of strategy violates the maxim(s) of Quality (do not say what you believe to be false; do not say that for which you lack adequate evidence).

(iv) When the argumentation contains a false proposition (see e.g., (5) and (6a-b) below) or when argumentation fallacies occur (cf. (7)-(12) below), the informative intention and the persuasive intention are recognized by the receiver and the persuasion knowledge allocates cognitive resources. In the case of argumentation fallacies manipulation is successful only if heuristic processing takes place, because systematic processing can uncover the incorrect way of argumentation. In terms of the Gricean theory, when the argumentation is fallacious, the communication is not cooperative, and the maxim(s) of Quality is (are) not observed.

\section{Influencing strategies in advertisements}

\subsection{Corpus}

Both the Hungarian and the American English corpora compiled for the present study consist of longer (minimum of 50 words) written advertisements that are not simply unscattered slogans, but rather are coherent discourses. Here, advertisement is understood in a wide sense where a 
firm wants to sell its image, its product or service. The analyzed texts vary in their types and topics and they come from three sources: 1. leaflets on display in pharmacies, department stores, 2. advertisements that appeared in newspapers, magazines, and 3 . direct mail.

\subsection{The communicator's strategies and their linguistic tools}

Written persuasion lacks the dynamism and the flexibility of oral communication, therefore different strategies are required in order to be effective. Written discourse, especially intended for larger audiences, is not a spontaneous way of language use; on the contrary, it is constructed carefully to fulfil the communicator's goals. Consciously designed and constructed discourse is called strategic discourse (Habermas 1984, 285-6).

The construction of advertisements is usually a longer process, the copywriters design several versions of the text that are corrected and tested before it appears in public. When the product is finally there with the readers, its writers are not present to adjust the discourse to the actual communicative situation and modify the ad according to the readership. However, for readers, the reception is not limited in time, the possibility of re-reading and re-interpreting is always there.

In the present analysis I will start with the assumption that every advertisement wants to influence the targets and make them believe the advertisement. Persuasion strategies are always applied and this fact is shared by the communicator and the readers, it is part of their mutual knowledge. In some cases, however, manipulative strategies are also presented along with persuasive strategies to make a greater impact on the readers.

The fact that there are immeasurable numbers of handbooks and guides available in bookstores and on the Internet proves that these strategies exist and thousands of people use them. The first and second type of manipulation (see 2.4.) cannot be examined in written ads. In the first case, withholding could be traced only from interviewing the copywriters or the manufacturers of the product. Let us suppose there is an advertisement for an expensive diet pill that promises weight loss in two weeks. The manufacturer may withhold the fact $\left\{I_{2}\right\}$ that the pill is not that efficient without making physical exercises every day. This genuinely useful information would be essential for the readers to know in order not to be misled. Certainly, this kind of manipulation will never be admitted by the manufacturer. The second type of manipulation could 
possibly be revealed from oral discourse and from a particular situation in a well-designed social psychological experiment. Strategies listed under (iii) can be quantitatively measured and compared, but their efficiency can be checked only empirically like in the experiments of Loftus (1979), and Semin and De Poot (1997) (see 2.3.). In the present study the fourth type of manipulation (fallacious argumentation) will be discussed in detail.

\subsubsection{The truthfulness of the discourse}

When the discourse contains a false proposition as in (5) and (6a-b) below, one or both maxims of Quality are violated (cf. 2.5.).

(5) Az Ariel Automat a legjobb a folteltávolításban.

'Ariel Automat is the best in removing stains.'

Stating that one's product is the best is very common in marketing discourse. However, this advertisement was scientifically proved to be false by chemists, and the manufacturer was fined for three million forints for misleading the consumers. Certainly, testing the truthfulness of ads is still very rare in the market.

The following two ads are based on false promise that is labelled by the rhetorics as raising unfounded hope (Szálkáné Gyapay 1999, 131) and by Breton $(2000,112)$ as misrepresentation. (6a) tells the readers that regaining youth is possible and vitality can easily be achieved by taking a certain kind of food-supplement, whereas (6b) promises a general solution to problems in life with the help of six spiritual tapes. These ads strongly simplify reality and promise success without real efforts.

(6) (a) A tudomány felfedezte azt az anyagot, amely energiát termel a testben. Sőt előállítása is sikerült, és amennyiben étrend-kiegészítő formájában veszi be, ezzel visszaállíthatja fiatalságát és életerejét.

'Scientists discovered and even successfully produced the material that makes energy in human body. If you take it as a food-supplement, you can get back your youth and vitality.'

(b) Get the latest audio program from Dr. Wayne W. Dyer and see how you can find a spiritual solution to all your problems by bringing love, joy and understanding into your life. 


\subsubsection{Argumentation fallacies}

Advertisements can be interpreted as argumentative discourses ${ }^{2}$ as well. The communicator wants to prove that the product (shampoo, diaper, vitamin etc.) is the best, most effective and that the reader undoubtedly needs it. Argumentation is one of the most important persuasive strategies, however, argumentation fallacies can function as manipulative strategies. The theoretical background of the analysis of argumentation fallacies in the present study is based on the pragma-dialectic list of fallacies which were collected by Eemeren-Grootendorst (1992) and also discussed by Walton $(1989 ; 1992)$. Their approach is normative, they all see fallacies as violations of the rules of critical discussions. The present section analyses some frequently applied argumentation fallacies.

A wide-spread persuasive strategy in advertising discourse is the "problem-solution" pattern, which can be potentially manipulative. The communicator calls the reader's attention to a specific problem and recommends his product or service as the only perfect solution to it, and this simplification carries the manipulative power. This strategy is very often combined with other persuasive or manipulative strategies.

(7) (a) A kisfiú mindössze 13 éves volt, amikor váratlanul hullani kezdett a haja. Szülei kétségbeesetten vitték orvostól orvosig, kórházról kórházra, végigjárták jó néhány természetgyógyász rendelőjét is - mindhiába, a teljesen megkopaszodott fiún senki nem tudott segíteni. Ekkor ismerték meg azt a termékcsaládot, amely Németországban az elmúlt 15 év során több tízezer ember haját adta vissza: a Sidhu-tinktúrát, -sampont és -sprayt.

'The little boy was only 13 when his hair suddenly started to fall out. His parents took him desperately from doctor to doctor, from hospital to hospital, they even visited the surgery of several natural therapeutics, but in vain. This entirely bald boy was hopeless, nobody was able to cure him. And then they found the Sidhu-tincture, shampoo and spray, which led to hair regrowth for thousands of people in Germany in the last 15 years.'

(b) Landing a dream job will take more than a high-school diploma. The hightech companies that are fueling the state's boom need workers with highlevel knowledge, skills and work habits. That's why Front Range Community College is the perfect choice for so many people, whether they want to start working right away or shoot for a job that requires a four-year degree.

\footnotetext{
${ }^{2}$ The analysis of argumentation is the subject of argumentation theory, which is a field of pragmatics. Argumentation theory is not a unifying concept; on the contrary, it is contributed to by several conceptually different disciplines such as logic, philosophy, sociology, linguistics, and rhetorics (Eemeren-Grootendorst 1995).
}

Acta Linguistica Hungarica 51, 2004 
A well-known rhetorical fallacy is the Post hoc, ergo propter hoc (false cause-and-effect) between two propositions: the fallacy involves concluding that A causes B because A occurs before B, but there is not sufficient evidence to actually warrant such a claim.

(8) (a) Az otthoni viseletre tervezett divatos papucsok biztosan támasztják, ugyanakkor gyengéden kényeztetik a lábat, hogy a következő reggelen újra frissen és pihenten induljon neki a napnak.

'These fashionable slippers especially designed for home use support firm and at the same time softly caress your feet to make your morning relaxed and fresh.'

Extract (8a) suggests that if we choose those particular slippers, we will be relaxed the next day, however, our relaxation obviously depends on many factors not only on the type of the slippers we wore the previous day.

(8) (b) In order to be successful, you have to look successful. That means more than merely shaving every day; it means shaving well-something that some razors simply don't do. The new MACH3 Turbo razor from Gillette, however, is different.

This ad implies that by using the new Turbo razor, we will look and be successful.

Very often Argumentum ad verecundiam (argument from respect, appeal to authority) is applied in advertisements. This can be a manipulative strategy if the text refers to unknown anonymous professionals or famous people who are not experts on the topic. When a well-known star tells of his/her pleasant experience about the advertised product (cf. (9a)), it is very often just a simple tie-up, since the star is not an expert of the quality differences, he/she was paid to give his/her face or words to the product. This strategy is based on respect for authority and the effect of role-models. The opinions of popular stars seem convincing and are always watched closely by millions.

(9) (a) Száraz, vízhiányos bőrömnek megfelelő kozmetikumokat használtam eddig is, de most már igyekszem egy termékcsaládot használni, mert így az arcápolók egymást kiegészítve fejtik ki hatásukat. [...] Számomra [Hegyi Barbara] az is nagyon fontos, hogy az Avon nem csak termékeivel segít szépnek és egészségesnek maradni, hanem sokat tesz is értünk, nőkért.

'So far I have used cosmetics suitable for my dry skin, but from now I will try to use one product range because they support each other's effect. [...] 
For me [Barbara Hegyi $]^{3}$ it is also very important that Avon helps not only to be beautiful with their products but also does a lot for us women.'

In (9b) the opinion of E. M. Forster, the respected and great writer, is quoted in order to convince the readers that Gibbon's book is worth buying. Since Forster is not a historian, his judgements on history books cannot be considered as a legitimate expert testimony, therefore the argument is fallacious.

(9) (b) Gibbon is a great navigator of the sea of history - the greatest whom this country, or perhaps any, has produced... Although the Decline and Fall came out two hundred years ago, it is still the leading authority on its period.

The following six examples show how appeals to emotion can lead to argumentation fallacies and therefore manipulate the readers. According to Walton $(1989,82)$, emotional overtones very often dominate advertising. In order to build emotional relationship with the readers, their instincts rather than their calculative reason are targeted. The major problem with fallacious appeals to emotion is that they are powerful distractions and thus can force the readers to accept arguments that are logically weak or irrelevant. In order to decide whether an argument is fallacious or not, careful analysis of the context is required.

The Argumentum ad populum fallacy primarily affects emotions and wants to popularize the product by quoting the words of satisfied and smiling people who allegedly have been using the product. The extract in (10a) comes from a Hungarian brochure advertising cards that introduce airplanes. The testimony section starts with the proposition: Ök már döntöttek... 'They have already decided...'

(10) (a) azóta másként nézek az égre; Nyugodtan mondhatom, nem bántuk meg; [Apa és fia] elválaszthatatlanok ezektől a kártyáktól; Nem tudtam ellenállni a nagyszerü ajánlatnak.

'Since then I look at the sky differently; I can surely say: we did not regret it; the father and his son are inseparable from these cards; I couldn't resist the great offer.'

The following two quotations $(10 \mathrm{~b}-\mathrm{c})$ along with several similar testimonies appeared in an English brochure that offers spiritual tapes.

(10) (b) I began using your program after attending your lecture in Denver. I couldn't believe how easy I started manifesting things into my life.

${ }^{3}$ Barbara Hegyi is a popular Hungarian actress.

Acta Linguistica Hungarica 51, 2004 
(c) If you hadn't fed me with such wonderful spiritual food, I would still be at the bottom of my financial hole.

When reading testimonies like this, some natural scepticism might arise about the alleged effects of the tape, especially in financial matters. However, we should admit that sometimes placebo-effects can occur and realize real improvements in one's life.

In the ads (11a-b) Argumentum ad misericordiam (appeal to pity) is discussed that aims at affecting emotions. The goal of (11a) is not to sell a given product, rather to build the image of a company. To strengthen the manipulative effect, the ad contains a false cause-and-effect relationship. The merging of the two companies is depicted as if it were planned for the sake of the patients.

(11) (a) A mai napon 139.000 ember hal meg betegségben idő előtt. Közülük több mint 25.000 öt év alatti gyerek. Ugyanakkor a mai napon a Glaxo Wellcome és a SmithKline Beecham cég egyesül. Ez azt jelenti, hogy most elöször több mint 100.000 kollegánk egyesíti a tehetségét világszerte azért, hogy megkeresse a betegségek okait, megtalálja az ellenszerüket, és segítsen a gyógyításukban.

'Today 139.000 people die of illness prematurely. 25.000 of them are children. And today Glaxo Wellcome and SmithKline Beecham are merging. This means that now, for the first time more than 100.000 colleagues are uniting their talent worldwide to identify the causes of many illnesses and find the remedy to help cure patients.'

The following English example depicts the miserable situation of the old very vividly and thus arouses pity.

(11) (b) Imagine being old and alone in our city. [...] Just imagine living on the fourth floor of a walk-up with dark, narrow stairs. Imagine your fear of falling if you have poor eyesight and osteoporosis. [...] We hope you will sign the enclosed placemat, so that a frail neighbor will know that someone is thinking of them.

This ad illustrates the difficulty of evaluating appeal to pity arguments. Many charitable pleas for aid use overt appeals to pity, however, it is not always an Argumentum ad misericordiam fallacy because in some cases pity is reasonable and legitimate (Walton 1989, 103-4). Considering the wider context of (11b) here the direct appeal to emotion of pity seems justifiable, therefore the argument is not fallacious.

$(12 \mathrm{a}-\mathrm{b})$ demonstrate an interesting combination of Argumentum ad baculum (appeal to force, threatening) and Argumentum ad populum, 
which Walton named as Bacpop argumentation whose aim is to persuade the readers to undertake a particular course of action $(1992,250)$. The argumentation seems like a warning, although the communicator puts pressure on the readers by mentioning unpleasant consequences and by implying threat of being excluded from a particular group the reader may want to belong to.

(12) (a) Bad Breath: Why you're always the last to know. A simple question: when someone you know or work with has bad breath, do you tell them? If you are like most people, the answer is probably "No." Which means that nobody is going to tell you when you have bad breath. So be sure you don't, use ReterDEX products. [...] So don't wait for someone to tell you. Because they won't.

The topic of the ad is so delicate and inconvenient that any potential involvement might frighten the readers, especially because the ad powerfully suggests (by creating a strong division between you and they) that everybody can have bad breath and thus be condemned and disliked by people, e.g., at workplace. The ad suggests that bad breath is embarrassing and it is desirable to belong to those people who have fresh breath.

(12) (b) I wonder, though, if you have yet appreciated the extent to which you may be missing out on important background material and information. Just think back to some of the events that have occurred since you received your last copy of Newsweek. Are you satisfied with your knowledge of the facts behind these and their full implications?

In this piece of direct mail the communicator uses argument from negative consequences and threatens the ex-subscriber that unless she continues subscribing the magazine, she will be ignorant and will miss the chance to have access to important information. Moreover, the letter wants to suggest that only Newsweek can provide reliable information on current issues.

\subsubsection{Style}

Although style was not considered as a separate manipulative strategy (see 2.4.), it has a crucial role in reinforcing the persuasive effect and the manipulative effect (in fallacious argumentation) of advertisements. Ads belong to strategic discourse, therefore linguistic choices are made consciously. The communicator chooses from the lexicon, the syntactic rules, and decides if he/she wants to deviate from the accepted norm. 
Style reveals what the communicator thinks about the cognitive capacity of the reader: the discourse can be reader-friendly or complicated, several propositions can be left implicit or implied. The more information is unexpressed, the larger mutual knowledge is presupposed between the communicator and the readers (Sperber-Wilson 1995, 218).

In his detailed study on persuasive discourse, Sandell (1977) showed that compared to non-persuasive discourse, advertisements contain significantly more adjectives and exaggerating expressions (e.g., superlatives and such words as always, never). Words are usually shorter and ellipses are often used. Sandell studied Swedish language advertisements only, but his observations seem to be true to advertisements written in German, Danish and English (128-135) as well.

The question how a given trope (alliteration, metaphor, repetition etc.) can function as a manipulative or persuasive tool in most cases can be answered only by analysing the whole discourse. If we take the trope, hyperbole (e.g., breathtaking collection, unbelievable offer, fit and energetic like never before), that is frequently applied in advertising discourse, it seems to violate the first maxim of Quality by stating untrue things. However, the readers can restore the truth-content of a false proposition and in the meantime they will form some hypothesis about the implicit message of the hyperbole (Nemesi 2003, 209). Therefore, tropes can function as a manipulative device only in a wider sense because the communicator may divert the readers' attention from the content and direct it toward the peripheral route of persuasion. Let us examine the hyperbole in the following advertisement.

(13) A Világ Repülögépei sorozat nem hasonlítható össze egyetlen repüléssel foglalkozó könyvvel sem.

'The World's Airplanes series is incomparable to any other books on aircrafts.'

This utterance (13) is a typical example of how hyperbole is presented in ads. It suggests that this is the best book on the topic and it is completely different from other books. However, these kinds of statements are so conventionalized that it became a part of the mutual knowledge between the communicators and the readers that the exaggerating expressions of advertisements should not be understood verbatim. Consequently, the hyperbole here (nem hasonlítható össze 'incomparable') does not violate the first maxim of Quality (unlike the hyperbole used in (5)) and therefore cannot be evaluated as manipulative. 


\subsection{Persuasive strategies}

So far only manipulative strategies were discussed but in order to carry out an in-depth complete analysis of an advertisement, persuasive strategies have to be spelt out as well. The most important persuasive strategy is non-fallacious argumentation. It can be rational or pragmatic (Habermas 1984). The former lists causes and facts to convince the readers:

(14) (a) S mivel a Braun Thermo Scan a dobhártya és a környező szövetek infravörös hőmérsékletét méri, különösen pontos eredményt ad, hiszen a dobhártya vérellátása megegyezik a hipotalamuszéval, amely a test agyi hőközpontja. 'Since Braun Thermo Scan measures the infrared temperature of the eardrum and of the neighbouring tissues, it gives a precise result, as the blood supply of the eardrum accords with that of the hypothalamus, which is the thermocenter of the human brain.'

(b) In a 1999 survey of FRCC students, 96.7 percent rated the quality of instruction as good or very good.

Pragmatic argumentation (see $(15 \mathrm{a}-\mathrm{b}))$ considers the desires, wishes and values of the readers. Very often the communicator chooses this kind of argumentation since the promise of fulfilling desires can be more effective than listing rational arguments (Kunst Gnamuš 1987).

(15) (a) Képzelje csak el, mennyi minden megváltozna az életben, ha egy ekkora nyeremény ütné a markát!

'Just imagine how much would change in your life if you won the Jackpot!'

(b) Think what you could do with $\$ 56,850$ or more right now!

When constructing an advertising argumentative discourse, the communicator may choose between one- or two-sided argumentation. In the first case only the positive sides are listed, which certainly suggests a certain bias from the communicator's side. The advantage of two-sided argumentation is that the system of counter-arguments can be explained by the communicator, therefore there is less possibility for the readers to come up with a new counter-argument. However, neither corpus contained two-sided argumentation.

In the structure of argumentation basically two schemes can be outlined (Kummer 1972). In progressive argumentation the communicator first lists facts, then arguments, and then draws a conclusion (that the readers should buy the advertised product). Progressive argumentation can use conjunctions such as: so, therefore, for this reason, that is why. In fact, the "problem-solution" pattern is based on progressive argumen-

Acta Linguistica Hungarica 51, 2004 
tation. In (16) reasons are listed for the aging of skin, and then comes the conclusion that by using Imedeen, the aging process can be stopped.

(16) Az életkor előrehaladtával bőrünk megújulóképessége folyamatosan csökken, vízhiányossá válik, a kollagén és elasztinszálak veszítenek rugalmasságukból. Az erős napsütés, a téli fütés és a légkondicionáló okozta száraz levegö, a szmog, a dohányzás is felgyorsítják az öregedési folyamatokat. [.. .] Az Imedeen hatásosságát sem napok, hanem hetek, hónapok alatt lehet tapasztalni, ám a szépség tartósan meg is marad.

'The revitalising ability of our skin is gradually decreasing with age, and the skin becomes dry, the collagen and elasthan fibres are losing their flexibility. The strong sunrays, the dry air caused by heating and air-conditioning, smog and smoking also accelerates aging. [...] The efficiency of the Imedeen capsule cannot be experienced in a few days but in weeks or months. But beauty is long-lasting.'

In the case of regressive argumentation (17) the conclusion is mentioned first, then supporting arguments follow.

(17) Open an Ameritrade cash account by March 15, 2001, with an initial deposit of $\$ 500$ or more, and you'll get 2,500 Mileage Plus Bonus Miles from United Airlines.

The two kinds of structures can be combined as in (18).

(18) Puffad? Görcsöl?

Egy szerrel elmúlik! Meteospasmyl.

Oldja a bélgörcsöket, megszünteti a hasi fájdalmat.

'Do you feel bloated? Have heartburn? Meteospasmyl stops them fast! It relieves heartburn and stops pain in the stomach.'

The first line of the ad describes the problem (the facts about having difficulties with digestion), the second line concludes that Meteospasmyl is the solution to it, finally, the third line lists facts about the mechanisms of how the proposed medicine carries out its effect.

Another persuasive strategy that can be applied in ads is the selection of a role for the communicator, i.e., narrator who can be e.g., an advisor, friend, teacher (Árvay 2003). When the communicator chooses a role for himself/herself, it will determine the distance and the power-relations (either equal or subordinate or superordinate) between the narrator and the reader. Roles that are traditionally associated with great respect (e.g., scientist, doctor) have persuasive effect on the readers.

Deciding on the degree of politeness can also function as a persuasive strategy. Readers of the ads usually appreciate politeness which evokes positive attitudes towards the communicator. Therefore, it is more probable that his/her words are believed and accepted. Politeness is reflected 
in the selection of linguistic elements such as modality and in speech act types. Let us now examine how role-selection and politeness can be used as a persuasive strategy in the next ad:

(19) A Mamád ugyanúgy megóv majd mindentől, ami Neked ártalmas lehet. [...] Ruháidat Ariellel mossa majd patyolattisztára, hiszen tudja és érzi, hogy ez jó Neked, addig is, amíg Te ezt nem tudod Neki elmondani.

'Your mom will protect you from everything that can be harmful to you. [...] She will wash your clothes white as snow with Ariel, because she knows that it is good for you until you can say this to her.'

The communicator does not address the target audience (parents) directly, instead literally talks to babies. Certainly it is only a stylistic device, since the baby cannot comprehend an ad. However, the artificial communicative situation (an adult recommends a product for a baby) makes the patronizing tone possible. The narrator takes the role of a nanny, uses informal verb forms in Hungarian, and as a result creates an unequal power-relation. The narrator avoids making a face-threatening act (Brown-Levinson 1987; Goffman 1955), protects the positive face of the reader, emphasizes his/her interests (this will protect you, this is good for you). In this unusual communicative situation with three participants (communicator, mock-addressee, real addressee), the narrator's role and position creates a friendly, informal situation which might evoke positive feelings in readers towards the advertised product.

With regard to the contrastive side of the analysis, English advertisements can also be characterized on the basis of the criteria listed above; however, a large-scale analysis may reveal which are the preferred tools. Rational versus pragmatic, one- versus two-sided, progressive versus regressive argumentation are all discourse organizational (rhetorical) issues, therefore they are likely to be culture-specific. According to a small-scale study (Árvay 2001), American ads tend to prefer regressive argumentation, whereas Hungarian ads use more progressive argumentation. The position of the communicator and the power-relations between the communicator and the readers determine a certain degree of politeness in a given advertisement, which is again highly culture-specific because different cultural conventions will result in different cooperative norms (Wierzbicka 1991). Preferred persuasive tools, i.e., the ratio of the listed persuasive criteria could well characterize the advertising conventions of a culture. However, it must be noted that advertising is an increasingly international genre which necessarily results in the homogenization of the ads.

Acta Linguistica Hungarica 51, 2004 


\subsection{Sample contrastive analysis of a Hungarian and an American direct mail}

In the sample analysis below, a Hungarian and an American direct mail will be examined in detail, its persuasive and manipulative strategies will be described according to the criteria listed above. Unlike in the United States, the genre of direct mail is a relatively new way of advertising in Hungary. Advertising agencies that prepare these letters in Hungary rely heavily on foreign direct mails. Additionally, if the recommended product is not Hungarian, the letter is very often the translation (with slight modifications) of a foreign mail.

\section{Kedves Árvay Anett!}

Most már hivatalosan is gratulálhatok ahhoz, hogy az előzetes szelekció során bekerült azon ügyfeleink közé, akik esélyesek a Reader's Digest Kiadó 16. ajándéksorsolásán, a 2004 díj bármelyikére - akár a 12000000 Ft-os Fődíjra is.

Amikor néhány nappal ezelőtt ezt megtudtam, azon kezdtem el gondolkodni, hogy mennyi mindent lehet csinálni ilyen nagy értékü díjjal. Biztos, hogy ekkora nyeremény gyökeresen megváltoztatja az ember életét. Most Önnek is lehet rá esélye, hogy kipróbálja. Hamarosan értesítjük, mit kell tennie ahhoz, hogy érvényesítse az ajándéksorsolásra szóló részvételi esélyét.

Ezt a lapot azért küldöm, hogy figyelmeztessem. Cselekedjen azonnal, amikor megkapja a Reader's Digest Kiadó borítékját.

Üdvözlettel:

Kádár Tímea

az ajándéksorsolási osztály vezetője

'Dear Anett Árvay,

Let me officially congratulate you on the result of the previous selection. You have got into the group of our clients who have a good chance to win part of the 2004 prizes and possibly the 12 million Jackpot of the 16th drawing of Reader's Digest Publisher.

When I learned this a few days ago, I started to think how much you can do with such huge winnings. I am sure that a prize like that changes one's life dramatically. Now, you have the chance to win. We will let you know shortly what you need to do to enforce your chance of participating in the Grand Drawing.

I am sending this card in order to warn you. Act immediately when you get the envelope of Reader's Digest Publisher.

Yours sincerely,

Tímea Kádár

head of the drawing department'

Acta Linguistica Hungarica 51, 2004 
Dear Stephen:

Think what you could do with $\$ 56,850$ or more right now! You could pay off highinterest debts and even have some cash left over. Because you're a homeowner, Guaranty National Bank can help you keep more of your hard-earned paycheck in your pocket and get the cash you need!

NO EQUITY? NO PROBLEM! A Guaranty National Bank Debt Consolidation Loan is a smart plan to help you regain control of your finances. Consolidate your debts into a lower, easy-to-manage monthly payment and have cash left over to use however you wish.

That's your savings of $\$ 621$ in your first month! Tax deductibility may increase savings (Consult your tax advisor).

NO EQUITY REQUIRED! Even if you do not have any equity in your home, call Guaranty National Bank at 1-800-350-5211 today. We can usually give you an answer in 15 minutes or less. Take advantage of your pre-approved status to consolidate your high-interest debts and the cash you need today.

CALL Guaranty National Bank AT 1-800-350-5211 TODAY!

P.S. Your Pre-Approved Voucher expires January 11, 2003, so act now!

The types of both ads are direct mail, which effect informality; however, every addressee is sent the same text except the salutation. Readers might consider this act as surprising or even appealing, and might wonder how the sender knows their name and address. The seemingly personalized letter may arouse interest and encourage the recipients to read it.

In the first utterance of the Hungarian ad (after the salutation) a manipulative strategy can be noted aiming at the peripheral route: raising unfounded hope. ${ }^{4}$ The letter offers congratulations on something that has not even been fulfilled and possibly will not come true, since the chances are so little, like winning the jackpot in the lottery. Another type of manipulative strategy, a presupposition (the inchoative verb bekerült 'got into') is applied in the first utterance which presupposes that someone was not in before. As the letter mentions previous selection, it can be implied that some people were left out of the circle of potential winners. This sounds suspicious and false. If I was never in contact

\footnotetext{
${ }^{4}$ In the present study the linguistic tools of persuasion and manipulation are studied. However, the analysis can be complemented with considering other, nonlinguistic factors, such as psychological factors or visuals. In this particular card two elegant glasses filled with champagne and a rose bouquet can be seen along with the inscription: Congratulations! Moreover, the card is written in letters imitating handwriting.
}

Acta Linguistica Hungarica 51, 2004 
with the company, did not send any application or order, how can I get into a second round? Since the postcard is accompanied by a long and detailed direct mail two days later, and that letter wants to convince the reader about subscribing to the magazine, there is no sense in the company limiting the number of potential customers. Isn't that more possible that "the previous selection" only means that the company had access to some addresses and did not have access to others? The second utterance of (20) is not true, since the writer (i.e., the narrator) of a mass-produced mail will not feel happiness and will not contemplate the potential prize. The discourse violated the first maxim of Quality (do not say what you believe to be false) used fallacious argumentation, thus manipulated the readers. ${ }^{5}$

Similarly, the English ad is manipulative as well, it also employs the strategy of fallacious argumentation. The first utterance (before the salutation) emphasizes a huge sum in big print. There is even a voucher certificate of $\$ 56,850$ attached to the letter that is filled in precisely. However, it becomes clear only from the tiny footnote that due to the restrictions, the real chances of obtaining that sum is very little, thus the ad raised unfounded hope. A presuppositional structure also realizes manipulation in the discourse: the application of the inchoative verb regain (regain control of your finances) presupposes that the reader did not have control over his/her finances.

With regard to the types of argumentation, the Hungarian ad uses pragmatic argumentation (tries to satisfy the dreams of the readers), whereas the English ad mixes pragmatic with rational arguments, it tries to prove the merits of the Debt Consolidation Loan.

The style of the Hungarian discourse is almost official. Comparing the parts of speech did not show any significant results: the ratio of verbs and nouns are balanced, there is no remarkable number of adjectives (cf. Sandell 1977). Abstract and concrete nouns are almost at an equal number. Repetition involves four lexemes: Reader's Digest Kiadó 'Reader's Digest Publisher' is used twice, the stem esély 'chance', the stem ajándéksorsolás 'drawing' and the stem dij 'prize' (including the compound noun Födíj 'Jackpot') are mentioned three times. Moreover, the latter stem has a synonym nyeremény 'winnings' in the original Hungarian text. In sum, lexical analysis shows a considerable number of

\footnotetext{
${ }^{5}$ As one of the referees let me know, this prize nearly-won type of advertisement was forbidden by law in Switzerland some years ago.
} 
lexical repetition which functions as a persuasive tool, as it emphasizes and reinforces the keywords for the readers. As opposed to the Hungarian ad, the style of the English ad is informal, with truncated sentences (e.g., No equity? No problem!) and contractions (you're, that's) being used. Lexical analysis showed that abstract and concrete nouns are almost in equal numbers here as well. The ad contains a considerable number of lexical repetitions: debt, cash and the name of the bank are repeated four times, pre-approved, more, equity, consolidate/consolidation and today three times, now and call twice.

Politeness in the Hungarian ad can be characterized as the following: the communicator, whose name and title are printed on the card, sets an official yet friendly tone, which somewhat decreases the relatively large distance. In the first part of the discourse the communicator avoids making a face-threatening act, the positive face is protected: she congratulates and expresses her joy (expressive illocutionary act: gratulálhatok 'congratulate'), then she makes a promise (comissive illucutionary act: értesitjük 'let you know'). The last utterance (before greetings and signature), however, sets a different tone: the communicator strongly threatens the positive face of the reader without redress. The powerful request or rather urging (directive illocutionary act: cselekedjen azonnal 'act immediately') is a typical face-threatening act and as such undermines politeness.

The English ad seems to be more direct than the Hungarian one. Calling the addressee by the first name only already suggests a great degree of informality and small distance between the communicator and the reader. However, the lack of a closing section and signature is disturbing. Face-saving and face-threatening acts are equally presented, since the communicator acts as an advisor and offers his help (comissive illucutionary acts: Guaranty National Bank can help you, we can give you), but at the same time powerfully requests the readers to act (directive illocutionary acts: think, consolidate, consult, take advantage, call Guaranty National Bank). The two imperative verbs act and call and the word today that are mentioned in the last section of the discourse urge the readers to contact the bank. From reading the post script, it becomes obvious that the readers are under emotional pressure, they are almost frightened with missing the deadline and the opportunity the bank offers for them. In spite of this, the argumentation of the last paragraph cannot be judged as fallacious (as an Ad baculum fallacy) because the discourse does not mention negative consequences if one decides not to take out the 
loan. Moreover, several reasons are listed to prove the merits of the Debt Consolidation Loan which make the urging acceptable. Lexical repetition here functions only as a persuasive and not as a manipulative tool.

To summarize the results of the sample analysis, the communicators in both advertisements used persuasive as well as manipulative strategies.

\section{Conclusion}

The first aim of the paper was to separate persuasion from manipulation. It was argued that in both cases the goal of the communicator is to have an opinion or fact accepted, however, in the case of manipulation it is camouflaged. Based on the ostensive-inferential model of communication (Sperber-Wilson 1995) two types of manipulation were identified. In the first, the communicator withholds certain information, i.e., besides the communicated $\{I\}$, an unuttered $\left\{I_{2}\right\}$ is also present. In the second type of manipulation no ostensive communicative intention is attached to the informative intention: the communicator can inform someone without his/her knowing that the information was intended for him/her. That means that the communicator forced the overhearer role on an outsider party. In the model of Harder-Kock (1976), manipulation is explained with the lack of mutual knowledge between the communicator and his/her partner, that is, the communicator possesses an information-surplus (cf. $\left\{I_{2}\right\}$ ). Another key theory in separating manipulation from persuasion was the Cooperative Principle and the maxims of Quality, Quantity and Manner (Grice 1975). Since manipulation is defined by the dictionaries and researchers as a negative form of communication, it is consequently not cooperative and the maxims are not observed, e.g., when certain information is withheld, the first maxim of Quantity is violated. The social psychological approach called attention to a third type of manipulation, where there is no withholding of information, or no ostensive communicative intention to the informed addressee. In the third case native speakers judge the discourse as logically correct and well-formed, but still it can be empirically proved that the discourse has a persuasive effect without the readers or listeners knowing about it. They influence the readers' subconscious, which means that we are not able to reveal how the linguistic stimuli affect us. In the present study, fallacious argumentation that was applied in persuasive discourse was regarded as a fourth type of manipulation. 
Based on the outlined types of manipulation, in the second part of the paper manipulative and persuasive strategies were collected from a corpus of Hungarian and American advertisements. Since the major characteristic of the advertisements is proving the prominence and the uniqueness of a product, advertisements were treated here as argumentative discourse. The quality of the arguments and the logical connections between them were analysed with the help of a list of argumentation fallacies (Eemeren-Grootendorst 1992; Walton 1989; 1992) that all violated the maxims of Quality. The study of style brought a less promising result as far as manipulative effect was concerned, since the maxims belonging to the category of Manner are too vague. Therefore it is not clear when they are not observed. The elements of style can become manipulative when applied in fallacious argumentation; in a wider sense, however, when tropes dominate an advertising discourse, they could divert the reader towards the peripheral route of persuasion and thus they could function as a manipulative tool. The quoted examples showed that under the mask of persuasion advertisements can mislead the readers and force them to believe and accept certain propositions by containing manipulative tools.

With regard to contrastive aspects of the paper, the outlined types of manipulation can all be detected both in the English and Hungarian languages. In the first and second types of manipulation, the communicative situation itself and not semantic elements or syntactic structures carry the potential realization of manipulation. In the third type, the manipulative mechanism is the same, although semantic presuppositional units or structures that induce manipulation are not all the same in Hungarian and in English. Argumentation fallacies exist in English as well, since logical mistakes in the course of argumentation are not language-specific.

The persuasive strategies can also be traced in the English advertisements. Nevertheless, only a large scale cross-cultural comparison would be able to show what the preferred strategies of each culture are. The perception and the acceptance of the same strategies could vary among cultures. The sample analysis in 3.4. suggested that for native Hungarian readers the American ad was more face-threatening and direct than the Hungarian but it is not interpreted by native English speakers as rude or pushy. It is important to emphasize once again that more empirical evidence is needed to prove the acceptance of persuasive strategies and the effect of manipulative strategies.

From a practical point of view, the analysis of persuasive and manipulative discourse can be useful for marketing experts, copywriters, 
researchers and instructors of reading comprehension, and for a wider audience to develop critical thinking.

\section{References}

Allport, Gordon W. 1968. The historical background of modern social psychology. In: Gardner Lindzey - Elliot Aronson (eds): The handbook of social psychology, 1-80. Random House, New York.

Aronson, Elliot 1972. The social animal. W. H. Freeman and Company, New York.

Árvay, Anett 2001. The analysis of persuasive discourse in English and in Hungarian written advertisements. Ms. Eötvös Loránd University, Budapest.

Árvay, Anett 2003. A manipuláció és a meggyőzés pragmatikája a magyar reklámszövegekben [The pragmatics of manipulation and persuasion in Hungarian advertisements]. In: Általános Nyelvészeti Tanulmányok $20: 11-35$.

Austin, John L. 1962. How to do things with words. Oxford University Press, Oxford.

Bańczerowski, Janusz 1997a. A nyelv titkai [The secrets of langauge]. In: Magyar Nyelvőr $121: 191-203$.

Bańczerowski, Janusz 1997b. A nyelvi közlés rejtett pragmatikai információiról [About the hidden pragmatic functions of communication]. In: Magyar Nyelvőr 121:4961 .

Brembeck, Winston L. - William S. Howell 1952. Politeness: some universals in language usage. Cambridge University Press, Cambridge.

Breton, Philippe 2000. A manipulált beszéd [Manipulated talk]. Helikon Kiadó, Budapest.

Brown, Penelope - Stephen Levinson 1987. Politeness: some universals in language usage. Cambridge University Press, Cambridge.

Chaiken, Shelly-Alexander Liberman-Alice H. Eagly 1989. Heuristic and systematic information processing within and beyond the persuasion context. In: James S. Uleman-John A. Bargh (eds): Unintended thought, 212-52. Guilford, New York.

Eagly, Alice H. - Shelly Chaiken 1993. The psychology of attitudes. Harcourt Brace, Orlando FL.

Eemeren, Frans H. van-Rob Grootendorst 1992. Argumentation, communication and fallacies. Lawrence Erlbaum, Hillsdale NJ.

Eemeren, Frans H. van - Rob Grootendorst 1995. Argumentation theory. In: Jef Verschueren - Jan-Ola Östman - Jan Blommaert (eds): Handbook of pragmatics: manual, 55-61. Benjamins, Amsterdam.

Goffman, Erving 1955. On face-work: an analysis of ritual elements in social interaction. In: Psychiatry $18: 213-231$.

Grice, H. Paul 1975. Logic and conversation. In: Peter Cole-Jerry L. Morgan (eds): Syntax and semantics, vol. 3: Speech acts, 41-58. Academic Press, New York.

Habermas, Jürgen 1984. The theory of action 1. Beacon Press, Boston MA.

Acta Linguistica Hungarica 51, 2004 
Harder, Peter-Christian Kock 1976. The theory of presupposition failure. Akademisk Forlag, Copenhagen.

Harré, Rom 1985. Persuasion and manipulation. In: Teun A. van Dijk (ed.): Discourse and communication, 126-42. Walter de Gruyter, Berlin.

Hovland, Carl I. - Irving L. Janis - Harold H. Kelley 1953. Communication and persuasion. Yale University Press, New Haven CT.

Howard, Daniel-Roger A. Kerin 1994. Question effects on generation and the mediation of attitude change. In: Psychological Reports 7:209-210.

Janis, Irving L. - Carl I. Hovland 1959. An overview of persuasibility research. In: Irving L. Janis - Carl I. Hovland (eds): Personality and persuasibility, 1-26. Yale University Press, New Haven CT.

Kecskés, Pál (ed.) 1998. Szent Ágoston breviárium [Breviarium of St. Augustin]. Kairosz Kiadó, Budapest.

Kelley, Harold H. 1967. Attribution theory in social psychology. In: David Levine (ed.): Nebraska Symposium on Motivation 15, 192-238. University of Nebraska Press, Lincoln NE.

Key, Wilson Bryan 1972. Subliminal seduction. New American Library, New York.

Kiefer, Ferenc 1983. Az előfeltevések elmélete [The theory of presuppositions]. Akadémiai Kiadó, Budapest.

Kummer, Werner 1972. Aspects of theory of argumentation. In: Elisabeth GülichWolfgang Raible (eds): Textsorten, 25-49. Athenum, Frankfurt.

Kunst Gnamuš, Olga 1987. Argumentation and persuasion. In: Frans H. van EemerenRob Grootendorst - Anthony Blair - Charles A. Willaard (eds): Argumentation: perspectives and approaches 3A, 103-109. Foris, Dordrecht.

Littlejohn, Stephen 1983. Theories of human communication. Wadsworth, Belmont CA.

Loftus, Elizabeth 1979. Eyewitness testimony. Harvard University Press, Cambridge MA.

Nemesi, Attila 2003. A túlzás szerepe a személyközi retorikában [The role of hyperbole in interpersonal rhetorics]. In: Általános Nyelvészeti Tanulmányok 20 : 195-219.

Németh T., Enikő 1996. A szóbeli diskurzusok megnyilatkozáspéldányokra tagolása [Segmentation of spoken discourses into utterance-tokens]. Nyelvtudományi Értekezések 142. Akadémiai Kiadó, Budapest.

Parret, Herman 1994. Indirection, manipulation and seduction in discourse. In: Herman Parret (ed.): Pretending to communicate, 223-238. de Gruyter, Berlin.

Petty, Richard E.- John T. Cacioppo 1981. Attitudes and persuasion: classic and contemporary approaches. W. C. Brown, Dubuque IA.

Petty, Richard E.-John T. Cacioppo 1986. Communication and persuasion: central and peripheral routes to attitude change. Springer-Verlag, New York.

Sandell, Rolf 1977. Linguistic style and persuasion. Academic Press, London.

Searle, John R. 1969. Speech acts. Cambridge University Press, Cambridge.

Searle, John R. 1976. A classification of illocutionary acts. In: Language in Society 5 : $1-23$.

Acta Linguistica Hungarica 51, 2004 
Semin, Gün R.-Christianne J. De Poot 1997. The question-answer paradigm: you might regret not noticing how a question is worded. In: Journal of Personality and Social Psychology 73:472-480.

Síklaki, István 1994. A meggyőzés pszichológiája [The psychology of persuasion]. Scientia Humana, Budapest.

Sperber, Dan-Deidre Wilson 1995. Relevance: communication and cognition. Second edition. Blackwell, Cambridge MA \& Oxford.

Szálkáné Gyapai, Judit 1999. Gyakorlati retorika [Practical rhetorics]. Nemzeti Tankönyvkiadó, Budapest.

Taillard, Marie-Odile 2000. Persuasive communication: the case of marketing. In: UCL Working Papers in Linguistics 12:145-74.

Thomas, Jenny 1995. Meaning in interaction: an introduction to pragmatics. Longman, Harlow.

Trew, Tony 1979. 'What the papers say': linguistic variation and ideological difference. In: Roger Fowler - Robert Hodge-Günter Kress - Tony Trew (eds): Language and control, 117-156. Routledge, London.

Walton, Douglas N. 1989. Informal logic: a handbook for critical argumentation. Cambridge University Press, Cambridge.

Walton, Douglas N. 1992. The place of emotion in argument. Pennsylvania State Press, University Park PA.

Webster 1998. Merriam and Webster's collegiate dictionary. 10th edition. Merriam and Webster, New York.

Wierzbicka, Anna 1991. Cross-cultural pragmatics: the semantics of human interaction. Mouton de Gruyter, Berlin.

Address of the author: Anett Árvay

Mohai köz 3.

H-1119 Budapest

Hungary

arvaya@freemail.hu

Acta Linguistica Hungarica 51, 2004 